\title{
Length-Weight Relationship and Spawning Season of Bagrus bayad (Forsskal, 1775) in Yamama Lake Kebbi State, Nigeria
}

\author{
Jega Ibrahim Shehu*, Daramola Ismail Maryam and Rasaq Ibrahim \\ Department of Forestry and Fisheries, Kebbi State University of Science and Technology, Nigeria
}

Submission: August 21, 2020; Published: October 01, 2020

Corresponding author: Jega Ibrahim Shehu, Department of Forestry and Fisheries, Kebbi State University of Science and Technology, P.M.B. 1144, Aliero, Nigeria

\begin{abstract}
The study was conducted to investigate the Length-weight relationship and spawning season of Bagrus bayad from Yamama Lake, Kebbi State Nigeria. Fresh fish catches of B. bayad were collected in batches from the fish landing site of Yamama Lake for a period of six (6) months, from April 2019 to September 2019. The parameter of Length-weight relationship of sampled fish was evaluated using the equation W=aLb. The Gonadosomatic Index (GSI) was determined using the formula, (Gonad weight/ Total body weight) x 100. The regression analysis of Lengthweight relationship for the male fishes was estimated as $\mathrm{W}=0.006 \mathrm{~L} 3.25$ indicating positive allometric growth pattern. For the females, the regression analysis was found as W= $0.009 \mathrm{~L} 3.077$ also indicating positive allometric growth pattern. Monthly mean GSI values for female were highest in June (2.79), indicating the peak spawning season. For increased spawning of B. bayad in Yamama lake, it was recommended that fishing should be restricted in June.
\end{abstract}

Keywords: Bagrus bayad; Length-weight relationship; Gonadosomatic index; Yamama lake

\section{Introduction}

High production capacity of members of Bagridae family in the wild has prompted many attempts by fisheries scientists to culture them. Chrysichthys nigrodigitatus have been cultured along with Tilapia melanoplura and Cyprinus carpio in Buguma, Nigeria, with encouraging results [1]. Bagrus docmac have been cultured with Tilapia in Uganda and being carnivorous, they were found to be effective in controlling Tilapia population. Many catfishes do not readily breed under captivity because they are not able to exhibit their natural spawning behavior in artificial ponds and this constitutes a limiting factor to their culture and mass production [2]. Bagrus bayad, also called bayad with local (Hausa) name Shambani is a member of Bagridae family which are commonly referred to as a naked catfish. They are commercially important species found in Nigeria fresh waters especially in Rivers and Lakes such as Niger, Kaduna, Benue, Lake Chad, and other inland waters [3]. The length-weight relationship (LWR) of fishes are important in fisheries biology and the study of natural history of fishes because they allow the estimation of the average weight of fish of a given length group by creating a mathematical relationship between them $[4,5]$. LWR can also be used to calculate condition indices, to compare life history and morphology of population belonging to different region and to study oncogenic allometric changes [6,7]. LWR is also an important factor in fish ecology and in the biological study of fishes, being of prime importance in parameterizing fish yield equation in stock assessment and management [8].

Studies on B. bayad had been limited to the growth, food and feeding habits and culture of its wild species $[9,10]$. No reported breeding program for $B$. bayad till date. The gonadosomatic index (GSI) is the calculation of the gonad mass as a proportion of the total body mass. It is a tool for measuring the sexual maturity of animals in correlation to ovary development and testes development. GSI is one of the important parameters of fish biology, which gives the detailed idea regarding the fish reproduction and reproductive status of the species particularly in identifying seasons of spawning $[11,12]$. The aim of the study was to provide information on the species gonadosomatic index and in the study area which might assist in the culture and breeding of the fish in captivity. 


\section{Materials and Methods}

\section{Study area}

The study area is in Yamama village, Kalgo Local Government Area of Kebbi State, Nigeria. The people of Yamama are predominantly fisher folks and farmers. Yamama Lake is a lake created from the Shella River, which sometimes floods into the lake. The lake, which is situated between latitude $11^{0} 20^{\prime}-12^{0} \mathrm{~N}$ and longitude $04^{\circ} 20^{\prime}-06^{\circ}$ East, stretches some $900 \mathrm{~m}$ in length and is $195 \mathrm{~m}$ wide giving a surface area of 17.5 hectares. The five fishing communities bordering Yamama are Rungumi, Nguwar Nenu, Janbaki and Yamama Ketare (Figure 1).

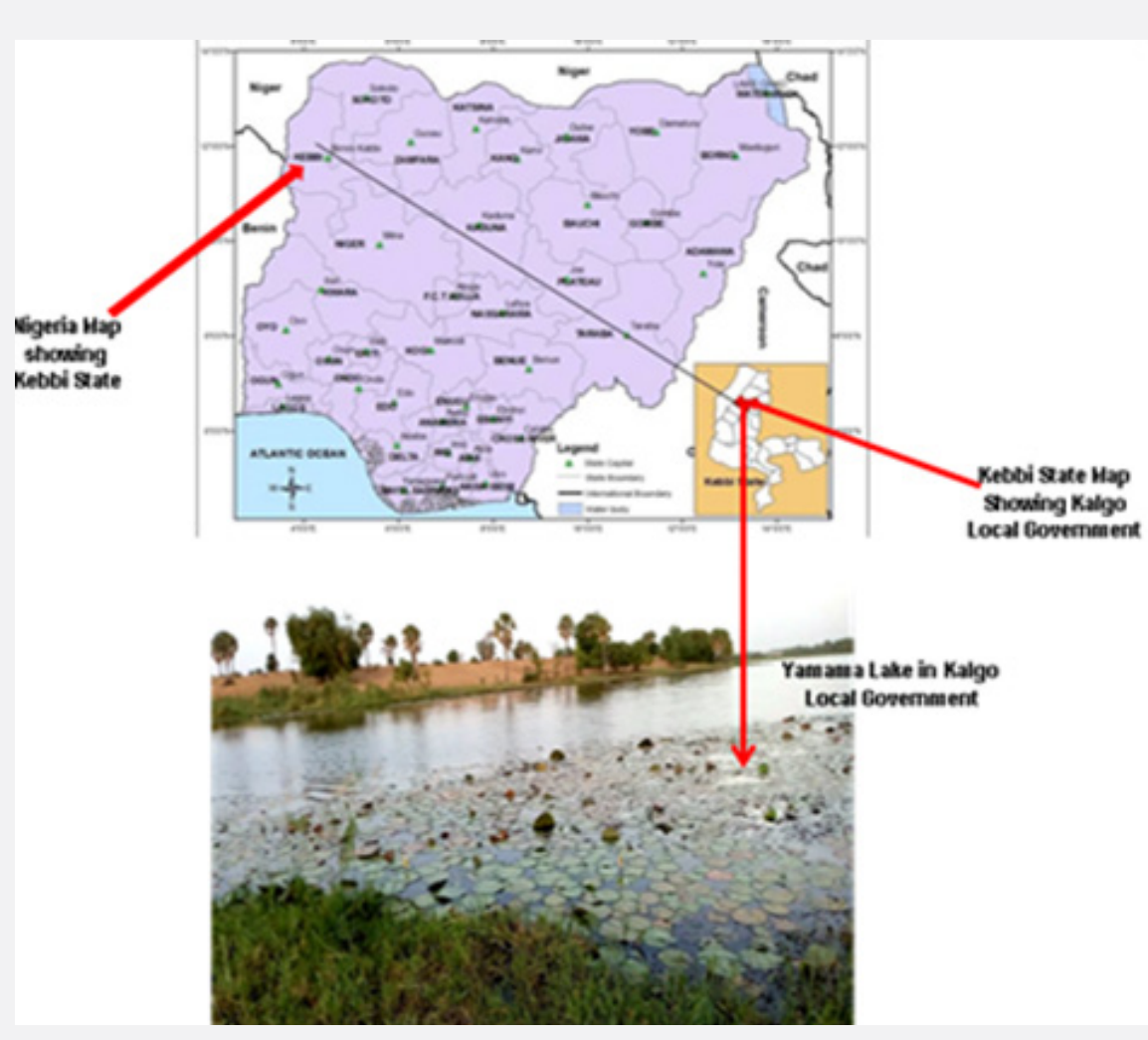

Figure 1: Map of Yamama Lake, Kalgo Local Government, Nigeria, showing site of sample collection.

\section{Collection of samples}

Fresh fish catches of B. bayad were collected in batches from the fish landing site of Yamama Lake for a period of six (6) months.

\section{Identification of the Species and data Collection Procedure}

The species was identified by counting of the barbells, fin rays and the position of the lateral line, using fish identification manual [13]. Total length (TL) was measured using a meter rule from the tip of the snout to the end of the caudal fin, Standard length (SL) was measured from the tip of the snout to the caudal peduncle, Fork length (FL) was measured from the tip of the snout to the separation of the tail. Body weight and gonad weight of the samples (g) were taken using an electric digital weighing balance.

\section{Sex determination}

Determination of sex was done by dissection method as described by [14].

\section{Determination of Length-weight Relationship}

The total length (TL) of each fish was measured from the tip of the snout (mouth closed) to end of the caudal fin using a meter rule. The body weight was measured using electric digital balance. The parameter of length-weight relationship of sampled fish was evaluated using the equation. [15]

$$
\mathrm{W}=\mathrm{aL}^{\mathrm{b}}
$$

Where, $\mathrm{W}=$ weight of fish $(\mathrm{g}), \mathrm{L}=$ length of the fish, $\mathrm{a}=$ the intercept, and $b$ the slope. The values of constants $a$ and $b$ were estimated after logarithmic transformation of $\mathrm{W}=\mathrm{aL}^{\mathrm{b}}$

\section{Determination of Gonadosomatic Index (GSI)}

The weight of the individual fish was taken, the female fish gonads were removed carefully, weighed on a sensitive weighing balance after removing the excess of moisture using a blotting paper and the length of the gonad were also taken. The GSI was determined using the formula: [16] 
GSI = (Gonad weight $/$ Total body weight $) \times 100$

The female mean GSI was computed monthly.

\section{Results}

\section{Fish size}

The standard length of the collected samples ranged from $23.00-32.90 \mathrm{~cm}$ and $22.10-34.40 \mathrm{~cm}$ for female and male fishes, respectively (Table 1). The weight of the fishes ranged from 135.0 $-472.0 \mathrm{~g}$ and $117.0-482.0 \mathrm{~g}$ for females and males, respectively.

\section{Length - weight relationships}

The Length weight relationship of both sexes of B. bayad was used to describe the growth pattern of the fish. The graphical representations of the Length - weight relationship of both the male and female B. bayad are shown in Figure 2 and 3, respectively. The regression analysis of Length-weight relationship for the male fishes was estimated as $\mathrm{W}=0.006 \mathrm{~L}^{3.25}$ (Figure 2), indicating positive allometric growth pattern $(b=3.25)$ while $r^{2}=0.912$. For the females, the regression analysis was found as $\mathrm{W}=0.009 \mathrm{~L}^{3.077}$ (Figure 3), also indicating positive allometric growth pattern $(b=$ 3.07) with $r^{2}=0.524$. The values of "a", "b" and $r^{2}$ were estimated. The relationship showed that the weight increases as the length increased as shown by positive b value and high correlation $\left(\mathrm{r}^{2}\right)$ values.

Table 1: Collection record of male and female B. bayad from Yamama Lake from April 2019 to September 2019.

\begin{tabular}{|c|c|c|c|c|c|c|}
\hline \multirow[b]{2}{*}{ MONTHS } & \multicolumn{3}{|c|}{ FEMALE } & \multicolumn{3}{|c|}{ MALE } \\
\hline & $\begin{array}{l}\text { No. of } \\
\text { fish }\end{array}$ & $\begin{array}{l}\text { Length(cm) } \\
\text { Min-Max }\end{array}$ & $\begin{array}{l}\text { Weight (g) } \\
\text { Min-Max }\end{array}$ & No. of fish & $\begin{array}{l}\text { Length(cm) } \\
\text { Min-Max }\end{array}$ & $\begin{array}{l}\text { Weight (g) } \\
\text { Min-Max }\end{array}$ \\
\hline APR & 5 & $\begin{array}{c}27.98 \\
(23.00-32.90) \\
\end{array}$ & $\begin{array}{c}316.2 \\
(178.00-472.00) \\
\end{array}$ & 1 & $\begin{array}{c}32.4 \\
(32.40-32.40) \\
\end{array}$ & $\begin{array}{c}419 \\
(419.00-419.00) \\
\end{array}$ \\
\hline MAY & 7 & $\begin{array}{c}27.56 \\
(23.20-32.20)\end{array}$ & $\begin{array}{c}232.29 \\
(135.00-417.00)\end{array}$ & 3 & $\begin{array}{c}27.07 \\
(22.10-31.20)\end{array}$ & $\begin{array}{c}230 \\
(117.00-348.00)\end{array}$ \\
\hline JUN & 4 & $\begin{array}{c}27.6 \\
(27.60-27.60)\end{array}$ & $\begin{array}{c}232 \\
(230.00-232.00)\end{array}$ & 2 & $\begin{array}{c}26 \\
(24.20-27.80)\end{array}$ & $\begin{array}{c}202 \\
(160.00-245.00)\end{array}$ \\
\hline JUL & 3 & $\begin{array}{c}26.43 \\
(24.70-28.10) \\
\end{array}$ & $\begin{array}{c}253.67 \\
(220.00-277.00)\end{array}$ & 1 & $\begin{array}{c}34.4 \\
(34.40-34.40)\end{array}$ & $\begin{array}{c}482 \\
(482.00-482.00)\end{array}$ \\
\hline AUG & 4 & $\begin{array}{c}24.83 \\
(23.08-26.30) \\
\end{array}$ & $\begin{array}{c}192 \\
(179.00-223.00)\end{array}$ & 1 & $\begin{array}{c}26.2 \\
(26.20-26.20) \\
\end{array}$ & $\begin{array}{c}231 \\
(231.00-231.00) \\
\end{array}$ \\
\hline SEPT & 2 & $\begin{array}{c}23.55 \\
(22.20-24.90)\end{array}$ & $\begin{array}{c}179 \\
(139.00-204.00)\end{array}$ & 3 & $\begin{array}{c}28.53 \\
(24.80-30.60)\end{array}$ & $\begin{array}{c}364.67 \\
(209.00-460.00)\end{array}$ \\
\hline
\end{tabular}

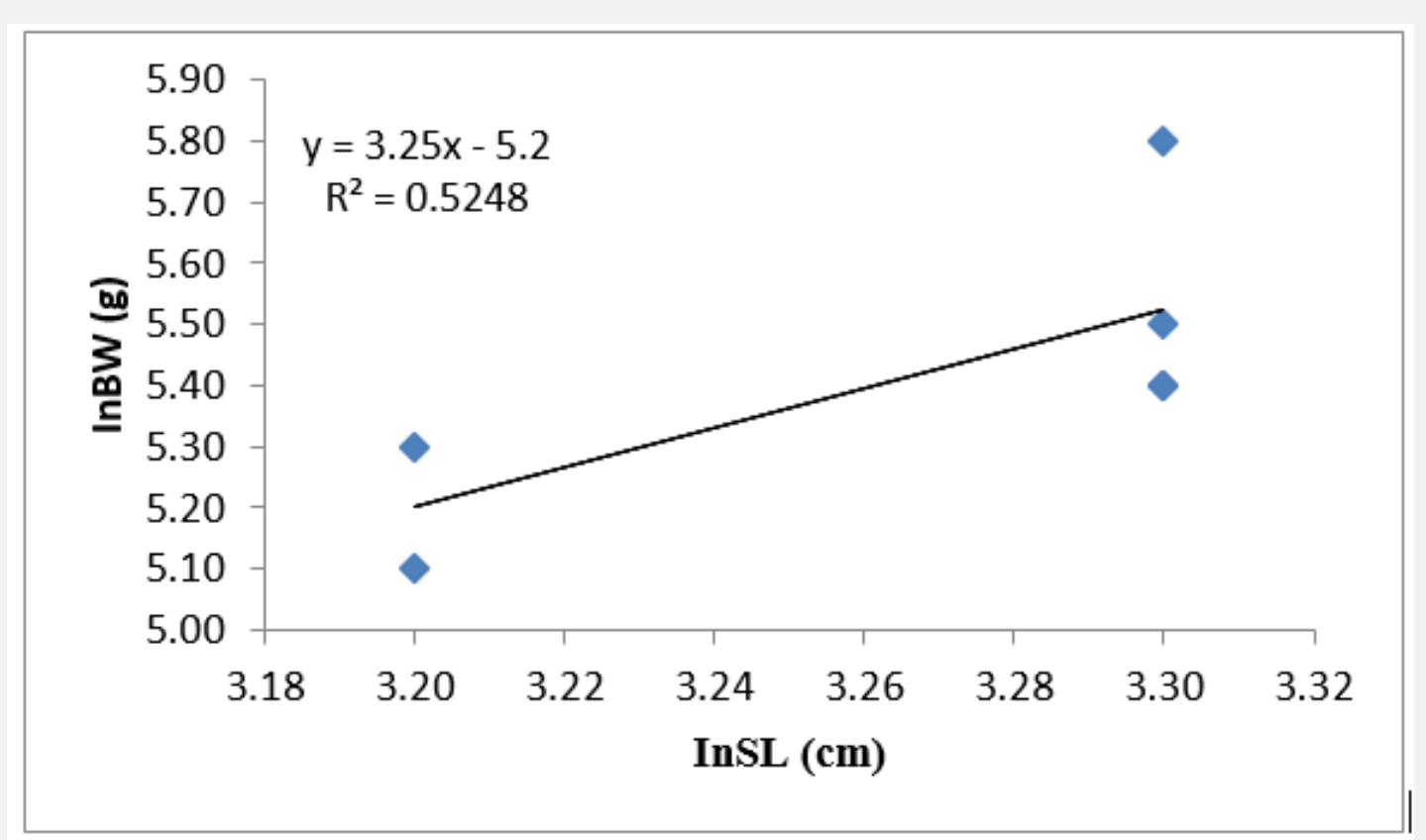

Figure 2: Length-weight relationship of male Bagrus bayad. 


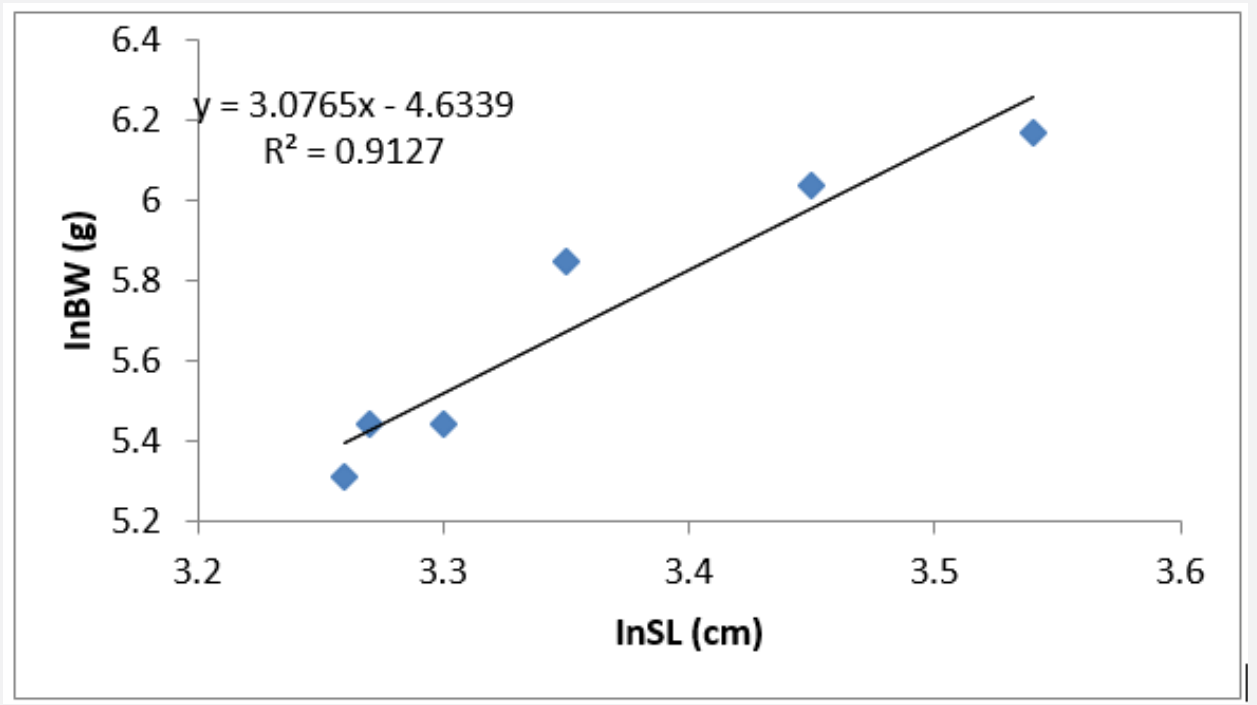

Figure 3: Length-weight relationship of female Bagrus bayad.

\section{Gonadosomatic Index (GSI)}

The mean monthly changes in GSI in female Bagrus bayad during the study period ranged from $0.14-2.79$. Plotting the average relative GSI against months (Figure 4), the values rises from 0.27 in April to 0.72 in May and the peak value of GSI was observed in June (2.79), indicating one spawning period within the period of April to September. The GSI then abruptly decreased from July to September. Results indicated that monthly mean GSI values for female were highest in June. Based on this, spawning season of B. bayad was found to be in June over the study period.

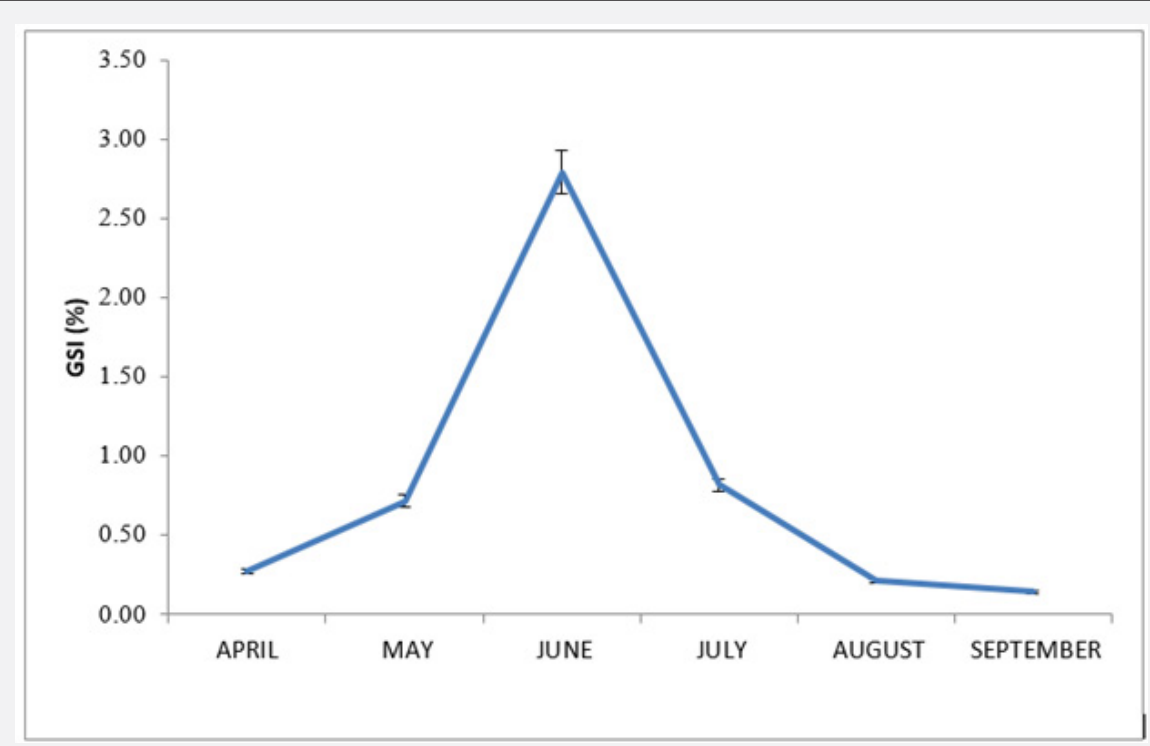

Figure 4: Gonadosomatic index of Bagrus bayad.

\section{Discussion}

The size ranges recorded in this study for Bagrus bayad indicated a rare phenomenon whereby the males were larger than the females in the waterbody. This agrees with Lewis [17] and Tsadu et al. [10] who reported that males of B. bayad recorded higher mean standard length and body weight than the females. The length weight relationship of fish is crucial in fisheries biology and their stock assessment because they help in estimating the fish's average weight of a given length category by estimating a mathematical relation between the two [18]. The values of "b" for both the male (3.077) and female (3.25) showed positive allometric growth pattern in Yamama lake. Nwabueze and Garba [19] reported positive allometric growth for Bagrus bayad from River Niger at Asaba and River Adofi at Ossissa in 
Southern Nigeria with b values of 12.864 and 14.637, respectively. Ogbe and Fagade [20] also found positive allometric growth for $B$. bayad from lower River Benue. Similar results were also reported for B. Bayad $(\mathrm{b}=3.1)$ and B. docmac $(\mathrm{b}=3.05)$ from Muess Channel, Sharkia Province, Egypt [9]. In contrast to this study, ElBadawy [21] found negative allometric growth for Bagrus bayad $(\mathrm{b}=2.8802)$ and Bagrus docmac $(\mathrm{b}=2.7858)$. Musa et al. [22] reported negative allometric growth for Bagrus bayad $(\mathrm{b}=2.364$ male; 2.714 female) and Clarias gariepinus (2.621 male; 2.676 female) in Thomas Lake, Kano State, Nigeria.

The differences in the reported $b$ values and the values from this study could be due to factors such as food availability in the waterbodies, prevailing weather conditions and difference in latitude. Gonadosomatic index (GSI) is a metric that represents the relative weight of the gonad to the fish weight. GSI has been widely used to evaluate reproduction timing [23]. The onset of spawning season is also defined by GSI. The highest value of GSI obtained in June (2.79) during the study period indicates the peak occurrence of mature individuals of Bagrus bayad. This was similar with Vinci [24] who recorded the peak values of GSI in female Silonia chidreni. Shaheena et al. [25] observed that GSI fluctuates from a minimum of 2.3 in June to 11.3 in March with decrease being indication of completion of spawning. This is in contrast with what Elsayed and Mohammad [26] reported that monthly variation in GSI for both sexes of Mormyrus rume followed nearly the same pattern and GSI showed higher values during the period from June to September with a peak in July, while the lower ones occur during the period from October to February. This is not in the case in this present study since the sampling period was not all year round.

\section{Conclusion}

This study revealed that the length-weight relationship of Bagrus bayad in Yamama lake showed a positive allometric growth which implies that this species grows fatter as the length of the fish increases. It is evident from the present study that the gonadosomatic index of freshwater B. bayad was higher in June, indicating that the spawning season of the fish is in June. To encourage increased spawning by B. bayad in the Yamama lake, fishing should be restricted in June. This information will be useful in formulation of more conservation strategies and policies for the species in the waterbody.

\section{References}

1. Bardarch KH, John HR and William OM (1972) Aquaculture: The Farming and Husbandry of Freshwater and Marine Organisms. John Wiley and Sons Inc. 244-255.

2. Lamai S L (1993) Aspects of the Applied Biology of Clarias garipepinus, Aquacultural Techniques and Deldrin toxicity. PhD Thesis. Department of Pure and Applied Zoology, University of Reading, UK, Pp. 204.

3. Holden M and Reed W (1972) West African Freshwater Fish. In: West African Nature Handbook. Longmans, UK, P.45.

4. Sarker O M (2008) Length - weight relationship and condition factor of two Bagrid fish (Bagrus bayad and Bagrus docmac). Journal of Fish

\section{Biology 45: 33-39.}

5. Mir DK (2012) Length - weight and length-length relationships of fish species from Aegan Sea (Greece). Journal of Applied Ichthyology 18(3): 200-203.

6. Tebiera de Mello R S (2006) The condition factor of fish from two river basins in Sao Paulo, Brazil. Acta Scienta Maringa 24 (3): 14-18.

7. Sani R, B K Gupta, UK Sarker, A Pandey, VK Dubey, et al. (2010) Lengthweight relationships of 14 Indian freshwater fish species from the Betwa (Yamuna River Tributary) and Gomti (Ganga River tributary). Journal of Applied Ichthyology 26 (3): 456-459.

8. Bagenal $\mathrm{T}$ (1978) Methods for assessment of fish production in freshwater. In: IBP Handbook No.3. Blackwell Scientific publications, Oxford London, USA.

9. El-Drawany M A and Elnagar W G (2015) Growth, food and feedings habits of Bagrus bayad and Bagrus docmac inhibiting Muess Channel, Sharkia Province, Egypt. Journal of Aquaculture Research and Development 6(7): 1-8.

10. Tsadu S M, Lamai S L, Yisa T A and Ibrahim S U (2014) Gonad Development and Histology in Bagrus bayad Cultured in Outdoor Earthen Ponds. Biological and Chemical Research 52-65.

11. Quasim SZ (1973) An appraisal of the studies on maturation and spawning in marine teleost from the Indian waters. Indian Journal of Fisheries 20(1): 166-181.

12. Chavan VR and Muley DV (2014) Study of gonadsomatic index and fecundity of fish Cirrhinus mrigala (Hamilton). The Bioscan 9(1): 167169.

13. Olaosebikan B D and Raji A (2013) Field Guide to Nigerian Freshwater Fishes. In: ( $2^{\text {nd }}$ edn.) Federal College of Freshwater Fisheries Research, New Bussa, Nigeria, Pp. 110.

14. Dewan S (1973) Investigation into the ecology of fishes of Mymensingh Lake. Bangladesh Agricultural University, Mymensingh, Bangladesh, Pp. 235.

15. Ricker W K (2004) Computation and interpretation of biological statistics of fish population. Fish Res Biol Canada Bulletin 191.

16. Anderson R O and Gutreuter S J (1983) Length, weight and associated structural indices. In: Nielsen L and Johnson D (Eds.), Fisheries techniques, American Fisheries Society, Bethesda, Pp. 284-300.

17. Lewis D S C (1974) An illustrated key to the fishes of Lake Kainji, Nigeria P. 67.

18. Beyer J E (1998) Length- weight relationship. Fish bytes 5: 11-13.

19. Nwabueze A A and Garba A A (2015) Growth pattern and condition factor of Bagrus bayad from two rivers in Southern Nigeria. Global Journal of Bioscience and Biotechnology 4(4): 330-334.

20. Ogbe FG and Fagade SO (2002) Distribution, abundance, and dimensional features of Clarotes laticep (Rupell) in lower River Benue, Makurdi, Nigeria. Journal of Prospects in Science 6: 18-23.

21. El-Badawy A A (1991) Biological Study on Some Fishes of High Dam Lake.

22. Musa H, Mahmud U, Safiyanu I, Bashir S I and Kutama AS (2016) Some Ecological Aspects of Bagrus bayad and Claria sgariepinus in Thomas Lake, Kano State, Nigeria. Global Advanced Research Journal of Agricultural Science 5(5): 165-174.

23. Lowerre-Barbieri SK, Henderson N, Llopiz J, Walters S, Bickford J, et al. (2011) Defining a spawning population (spotted seat rout Cynoscion nebulosus) over temporal, spatial, and demographic scales. Marine Ecology Progress Series 105-142. 
24. Vinci G K (1984) Some aspects of the biology of Silonia children (sykes) from Nagarjuna sagar reservoir, Andhra Pradesh, India. J Inland Fish Soc India 16 (1\&2): 25-31.

25. Shaheena S, Yousuf A R and Muni P (2012) Study on the fecundity of Cyprinus carpio communis (Linneaus, 1758, introduce). International Journal of Scientific and Research Publications 2(2): 1-5.
26. Elsayed A K, Mohammed M N A (2012) Interaction of the Mormyrid fish, Mormyrus kannume (Forsskal, 1995) reproduction and feeding intensive with the environment in a Nile Delta Canal, Egypt. Egypt J Aquat Biol \& Fish 16(1): 73-94.

\section{Your next submission with Juniper Publishers will reach you the below assets}

- Quality Editorial service

- Swift Peer Review

- Reprints availability

- E-prints Service

- Manuscript Podcast for convenient understanding

- Global attainment for your research

- Manuscript accessibility in different formats ( Pdf, E-pub, Full Text, Audio)

- Unceasing customer service

Track the below URL for one-step submission https://juniperpublishers.com/online-submission.php 